\title{
An Exploration of the Predictors of Relationship Status with a Caveat on Interpretation*
}

\author{
Antony Mastroniani1,2 \\ ${ }^{1} \mathrm{BA}$, Cornell University, Ithaca, NY, USA \\ ${ }^{2} \mathrm{MA}$, Columbia University, Manhattan, NY, USA \\ Email: afm2105@gmail.com
}

How to cite this paper: Mastroniani, A. (2017) An Exploration of the Predictors of Relationship Status with a Caveat on Interpretation. Open Journal of Applied Sciences, 7, 412-432.

https://doi.org/10.4236/ojapps.2017.78031

Received: June 20, 2017

Accepted: August 28, 2017

Published: August 31, 2017

Copyright $\odot 2017$ by author and Scientific Research Publishing Inc. This work is licensed under the Creative Commons Attribution International License (CC BY 4.0).

http://creativecommons.org/licenses/by/4.0/

\begin{abstract}
Using the Puerto Rican Maternal and Infant Health Study dataset (PRMIHS), the predictors of relationship status were examined via probit regression. The strongest predictors of relationship status found were interactions between binary variables for the age that a respondent first had sexual intercourse and for the age that a respondent first entered into a union $(\mathrm{N}=1452)$. This paper concludes by arguing that the results provide support for viewing union status as being primarily dependent on the people involved in the union instead of being primarily dependent on factors external to the people themselves.
\end{abstract}

\section{Keywords}

Divorce, Separation, Union Status, Union Stability, Relationship Status

\section{Introduction}

The predictors of relationship status are often viewed from an "external to the person" perspective instead of from the viewpoint that these predictors are often reflective of intrinsic qualities of the people in the relationship. While a relationship's status is surely not entirely determined by qualities intrinsic to the people in that relationship, the results of this paper indicate that relationship status is best determined by examining the actual people in a relationship.

\section{Literature Review}

One prominent approach to analyzing divorces/separations nowadays is the ra-

*The following paper is a revised version of the author's MA thesis, which he completed in late '06. 
tional choice model. In the context of relationships, this model posits that people will stay in relationships when it is in their own best interest to do so and end them when the overall cost of remaining in them exceeds the benefits of doing so, hence maximizing their utility. Using this logic, the positive relationship sometimes found between the household division of labor (i.e. specialization) and union stability is perceived as reflecting the greater costs incurred by exiting a relationship in which the partners have grown increasingly dependent on each other due to increasing specialization [1] [2] [3] [4]. In regards to a wife's income, this outlook has explained the sometimes negative association between said measure and union stability as reflecting the lessened costs for a wife to exit a relationship when her income has risen [5]-[11]. As for the frequently found negative relationship between age at marriage and union stability, this perspective has argued that it reflects the longer payoff period a person has to find another partner when he/she ends a relationship while young as opposed to while older [10] [12]. The negative relationship between female labor force participation and union stability, meanwhile, has been explained as resulting from the greater number of attractive partners made available to men via said factor [13].

In addition to the findings mentioned in the preceding paragraph, there are others to which the rational choice viewpoint has been applied. The negative relationship between union dissolution and investments in a relationship via things such as time spent in union, children, and home ownership has been explained as resulting from the greater costs incurred by exiting a union with more of these investments [9] [11] [12] [14] [15] [16] [17]. Additionally, the sometimes found positive relationship between a couple having a boy and union stability has been viewed as reflecting the greater costs for fathers to leave unions in which they have put more time and energy into due to their greater involvement with a male child vis-à-vis a female child [18] [19] [20]. At the same time, the sometimes positive relationship which has been found between a wife's income and union stability has been deemed as resulting from the reduced benefit of exiting a relationship in which a wife's income, if pooled, has benefited the entire family and relieved the economic pressure on the husband [8] [21].

Another major, related approach in the literature on relationships is to examine certain variables, particularly demographic ones, and to explain their importance in terms of what they provide instead of looking at them in terms of what they reveal about the person. One such variable is education, which some have argued reflects communication skills needed to maintain relationships [9] [22] [23], while one study by an author named Ono argued that in specific regards to a wife's education, it only affects relationships through earnings [9]. In that study, however, even when a wife's earnings were controlled for, the response of "no information" given for a wife's education had a statistically significant positive effect on marital dissolution [9]. This finding may be caused by the possibility that women in that dataset who had little or no education preferred to give no information on that variable, consistent with the social desirability phe- 
nomenon sometimes found in surveys [24] [25]. If so, Ono's claim that a wife's education only impacts relationship status via earnings may be contradicted [9]. The resources available to a husband, meanwhile, as measured by things such as percentage of time working in a given period and his level of education, have been looked at as proxies for income/resources which can be made available to stabilize relationships [6] [9] [13] [16] [26]. In addition, age at marriage has been described as reflecting less knowledge of proper role performance in marriage [16] and as a proxy for time spent gathering info as to whether someone is a suitable partner [10]. In regards to domestic violence and other stressful events, the negative relationship between these things and union stability has been explained as being a result of the reduced benefits to staying a relationship which has had its quality lowered due to strain [27] [28] [29].

The preceding two paragraphs, it should be noted, are not meant to be taken as exhaustive. Whether one identifies as Catholic, for instance, has been examined on the grounds that identifying oneself as such would reduce the likelihood of union dissolution due to said religion's views on divorce [10] [30]. A couple's degree of similarity in regards to things such as education and ethnicity, meanwhile, has been looked at with the belief that greater dissimilarity leads to greater conflict and hence less union stability [31] [32]. The effect of tax rates has also been examined [33], as has the often found negative relationship between cohabitation and union stability of cohabitation [30] [34] [35] [36] [37] [38], the effect of welfare reform [39] [40], and there are numerous other factors, as well. A complete overview will not be undertaken, however, for entire papers have been devoted to such attempts [41] [42].

\section{A Different Perspective}

Referring back to the title, the caveat which will be mentioned is that this author believes that some of the aforementioned variables should be examined in the light of what they reveal about the actual persons involved in the relationship. This action should by no means be taken as an assumption that events which happen during a relationship do not matter for its stability, however, for what actually happens during one surely plays some role in its eventual outcome. What it does indicate is that it is this author's viewpoint that things such as domestic violence, whether a partner has gone to jail, level of educational attainment, etc., should be viewed primarily as indicators of the actual people involved in the relationship. Looking at unions as ventures/agreements that are usually between two parties which require skills such as the ability to communicate, compromise, and think calmly in regards to the long-term future (and hence delay gratification) to achieve long-lasting stability, it is hereby hypothesized that people who are able to succeed in other endeavors that require at least some of these same skills, such as attaining a good paying occupation and saving enough over the long haul to buy expensive items such as a home, will be more likely to achieve long-lasting union stability than those people who cannot. Un- 
fortunately, this hypothesis cannot be used to show cause, for it is a subjective interpretation of available facts. It should be pointed out, however, that for whatever reason, results obtained from data in this field, which if not completely non-experimental is overwhelmingly so, are oftentimes referenced in a way that implies that they reveal causation. All attempts will be made in this paper to avoid that error, for this analysis is based on non-experimental data (i.e. survey data).

Before moving on, a few more points need to be made. Firstly, the "types of people" argument has been made previously, as when authors such as Morgan and Rindfuss [43] and South and Spitze [16] argued that the positive relationship between age at marriage and union stability exists because age at marriage can be seen as a proxy for maturity. But as any even cursory survey of recent journal articles regarding this subject would reveal, that this focus is not the predominant one in this field today. Secondly, the conclusion that the assignment of responsibility for relationship status should primarily be placed with individuals is supported by many biological studies which have directly examined divorce via behavioral genetics studies [44] [45] [46] and testosterone studies [47]. Thirdly, testosterone has been linked indirectly to marriage in numerous studies that have demonstrated a link between it and things known to affect marital stability (e.g. antisocial behavior, occupational attainment) [48] [49]. Fourthly, as noted by Johnson et al. [45], the genetic influence on personality has been well established [50], which is noteworthy considering that as some such as Teachman have noted [51], several personality traits have been linked to divorce [44] [46] [52] [53] [54] [55]. Lastly, the debate regarding the importance of individual factors vis-à-vis external/situational factors is an old one, as when Reinhold Niebuhr criticized many liberal thinkers for placing the blame for the ills of the world primarily on situations and institutions rather than on human beings themselves [56]. Given the recent dominance of rational choice models in this field, however, it was decided to make this point of difference clear.

\section{Data}

The dataset which will be used in this paper is the Puerto Rican Maternal and Infant Health Study (PRMIHS), which consists of 2763 personal interviews with mothers of infants drawn from two independent samples. Because this paper is attempting to determine what predicts the failure or sustaining of relationships, including marriages, only those mothers who gave information on union status and who did not respond that they never married or that they were widowed to the question regarding current marital status will be examined. The sample size will further be reduced by excluding people who gave no information on variables considered to be important for this analysis, thereby reducing the final sample to 1452 respondents.

\subsection{Dependent Variable}

All dummy variables were coded as either 0 or 1 , as per convention, and all biva- 
riate regressions mentioned hereafter regarding dummy variables utilized probit regression.

Current marital status: A dummy variable was created to deal with respondents who answered that they were divorced or separated from their partner at the time of their interview. It should be noted that due to question wording, it is possible that some mothers had been in relationships which had ended and then gotten into ones which were still existent. If anything, this possibility would make it seem as if relationships had been more stable than they actually were. Lastly, there was a question in the PRMIHS survey asking about first union status, but not much data pertaining to that time in the respondent's life was available. Current marital status was therefore examined instead.

\subsection{Independent Variables}

\subsubsection{Variables Pertaining to Living Situation and Partner Quality}

Living status and partner quality: Dummy variables pertaining to whether the respondent had been living with the father of the focal child at time of conception and to whether the respondent's partner had hit her or been to jail were interacted in these analyses. The latter dummy variable was initially entered by itself into models to test the hypothesis that relationship stability is contingent upon the quality of one's partner. It was not entered by itself into final regressions, however, because a bivariate regression between that dummy variable and the aforementioned one pertaining to living situation revealed that a 1 value for the latter lowered the chances of a 1 value for the former by $12.2 \%(\mathrm{p}<0.02)$.

It should be noted that including the living situation dummy variable followed the lead of Oropesa and Landale [29] on the grounds that relationships where the partners lived together at time of conception would be more stable than ones where they did not. Additionally, whether a respondent's partner had hit her or been to jail was interacted because a bivariate regression revealed that an answer of "yes" to whether the respondent's partner had been in jail raised the likelihood of the respondent having been hit by her partner by nearly 38.5\% ( $\mathrm{p}<$ 0.0001). The decision to require that the respondent's partner had both hit her and been to jail was foregone, however, because this concurrence occurred in only 13 cases in the final sample. Lastly, the interaction with a positive value for instances when the respondent lived with the father at the time of conception and where her partner had not been to jail or hit her served as the base category by author's discretion.

\subsubsection{Partner Similarity Variables}

Education: Dummy variables regarding whether the respondent had completed the $11^{\text {th }}$ grade at most and the father had completed 16 or more grades were interacted.

Ethnicity: Whether the father of the focal child was Puerto Rican and whether the mother identified herself as Puerto Rican under ethnic identification were examined. At first, a dummy variable dealing only with the father's ethnicity was 
created, but later analyses showed that results with this dummy were essentially identical. The choice to use the dummy with both partners' ethnicity was thus made solely by author's discretion.

\subsubsection{Age First Union - Age First Sexual Intercourse Interaction Variables} Age first union and age first sexual experience: Dummy variables for whether the respondent's first union occurred before the age of 27 and whether her first sexual experiences occurred at the age of 17 or later were created due to the logic of previous hypotheses regarding long-term thinking, patience, etc. These two variables were not entered separately into final equations, however, but were instead interacted because a bivariate regression between them revealed that a 1 value for the latter dummy variable lowered the chances of a 1 value for the former one by nearly $33.4 \%(\mathrm{p}<0.0001)$. It should be noted that the decision was made to eschew continuous measures of age at first union and age at first sexual intercourse for the following reasons: 1) to diminish the impact of extreme responses given (e.g. in the final analyses, there were 22 values of 13 or less for age at first union when it was asked for in years and eight values of 11 or less for age first time when measured in years); 2) measuring age at these events as a continuous variable seems to imply that there are important cognitive differences between people when there is none (e.g. how much more mature is a 25.3 year old respondent from a 25 year old one, or a 14 year old from a 15 year old?); 3) using a continuous variable implies that there is a constant effect for every year added agewise, but results indicated that this condition was not present (i.e. not delaying one's first union until 22 or 23 raised the chances of a positive value of the dependent variable more than entering one's first union before the age of 20).

Before moving on, it must be pointed out that it is of course possible that these variables will be affected by things other than the aforementioned traits such as social reclusiveness. This trait, which would probably increase the respondent's age at loss of virginity and presumably at first union, but the PRMIHS survey does not provide data suitable for this type of alternative analysis (i.e. it does not ask respondents about their social tendencies or habits). It is also possible that delaying one's first sexual experience until the age of age or later reflects adherence to traditional values, but again, this possibility cannot be further explored due to data constraints. Furthermore, alternate forms for the variables forming the basis of this interaction which used different age cutoff points were created. Results for regressions with these variables serving as the basis for alternate interactions were not substantially different. The connection between age at first union and age at first sexual encounter, meanwhile, remained strong when measured in continuous form (R-Squared $=0.569 ; \mathrm{p}<.0001$ ). Lastly, 27 and 17 served as the cutoff points for age at first union and age at first sexual experience, respectively, by author's discretion.

\subsubsection{Stressful Events Variables}

Difficulty with bills and health of a loved one: Pertains to respondents who were 
unable to pay their bills and who had a loved one fall into poor health. In the survey which provided the basis for the Puerto Rican Maternal Infant and Health dataset, respondents were asked if someone close had died, if a close family member had been hospitalized, and if they had been unable to pay their bills. The answers to these three questions will not be used as part of an index, as in prior research [29], but they will be used in this paper to form interaction variables. A dummy for instances where someone close was not well was created by multiplying one dummy with a positive value for instances where a relative was in the hospital and another dummy for a positive value in cases where someone close died after a bivariate regression showed that a yes response to one of these questions raised the probability of a yes response to the other one by approximately $32.1 \%$ ( $\mathrm{p}<0.0001)$. An interaction variable representing respondents who could not pay their bills and who had someone close be not well was then created by multiplying a dummy for respondents who could not pay their bills by a dummy for instances where someone close to the respondent was not well after a bivariate regression showed that a 1 value for the bills dummy raised the chances of a 1 value for the loved one's health dummy by close to $9.9 \%$ ( $\mathrm{p}<$ $0.01)$.

The interaction where the respondent could pay her bills and no loved one was ill served as base category by author's discretion. Additionally, a different dummy variable regarding financial difficulties was created and it served as a part of interactions with the health of a loved one dummy also. Results for models with these variables were essentially identical. Furthermore, previous research had included whether someone close to the respondent had had problems with substance abuse [29]. A bivariate regression, however, revealed that a yes response to whether someone close had abused substances raised the likelihood of a 1 value for the aforementioned dummy pertaining to a partner's having hit the respondent or having gone to jail by approximately $33.4 \%(\mathrm{p}<0.0001)$. This question was thus not be used as a stressful event variable. In the same light, respondents had been asked if they had been in a fight as an indicator of stress, but a bivariate regression between this answer and the dummy pertaining to a partner having hit the respondent or having gone to jail showed that a yes response to one of these questions raised the probability of a yes response to the other by $44.8 \%(\mathrm{p}<0.0001)$. Whether the respondent had been in a fight was thus not used as part of a stressful event variable, either.

\subsubsection{Variables Dealing with Education and Money}

Education and income: Dummies were created regarding whether the respondent had attained at least a Bachelor's degree and whether her combined household income at time of pregnancy was at minimum 25,000 dollars. The decision was made to interact these variables because a bivariate regression between them revealed that 1 value for the education dummy raised the chances of a 1 value for the income dummy by nearly $35.5 \%$ ( $\mathrm{p}<0.0001)$. Furthermore, by interacting these dummy variables, it may be possible to determine whether it is increasing 
levels of money or of education which has the stronger effect on union stability. As for measurement decisions, it was decided to measure education and income dichotomously for reasons similar to the ones already given for measuring age at first union and at first sexual intercourse dichotomously. They are: 1) measuring education at the interval or ratio level suggests that there may be differences between people when there actually is none, at least not substantively (i.e. there may be no meaningful difference between someone who drops out of school after $10^{\text {th }}$ and someone who drops out of school after 11th grade); 2) there may be an important difference between people who complete a certain phase of schooling (e.g. college) and those people who merely begin it (i.e. different levels of diligence, rational long-term decisionmaking ability, etc.-also sometimes referred to as the Glick effect). 3) in regards to income, there is a possibility that the effect of each additional dollar which a person possesses is not constant and that instead there are instead meaningful thresholds which should be sought out (e.g. minimum monetary amount needed to pay rent).

No separate dummy variable was constructed for people who go on to complete Master's or $\mathrm{PhD}$ level studies due to the small number of respondents who did so. Additionally, alternate dummy variables for income using different cutoff points such as $\$ 15,000$ and $\$ 30,000$ were created, but multivariate regressions with them did not differ substantially from the one presented here. Additionally, there was no sure way to determine if respondents had dropped out of high school or college once beginning it, thereby making it impossible to examine a possible dropout effect. Lastly, the interaction representing respondents who had not attained at least a Bachelor's degree and whose combined household income was under $\$ 25,000$ served as the base category by author's discretion.

\subsubsection{Variables Pertaining to Religion}

Religious denomination and frequency of service attendance: Separate dummy variables representing Catholics, Protestants, and non Catholics or Protestants were created to check for an effect of religion on union dissolution and to avoid homogenizing people belonging to different religious sects. At the same time, a dummy variable pertaining to whether a respondent attended religious services once a week or more was created and then interacted with the religious denomination dummies. This decision was made for the simple reason that religious people who attend services frequently (here defined as at least once weekly by author's discretion) may be different from people of the same faith who do not show such devotion to it. Respondents who did not identify themselves as Protestant and who did not attend religious services at least once weekly served as the base category by author's discretion.

\subsubsection{Additional Variables}

Prior fertility. The number of births the respondent had before the birth of the study's focal child was entered into final analyses.

No prior children: A dummy variable dealing with the specific instances 
where the focal child was the union's first was included.

Sex of child: A dummy variable dealing with whether the focal child was female was included.

It should be noted that a dummy variable regarding instances where the focal child was the couple's first child and a girl did not substantially alter the final model and was thus dropped.

\subsubsection{Variables Purposely Not Included}

Father's age at pregnancy. Although a variable for the father's age at pregnancy could have been very valuable considering the numerous studies showing that there is a relationship between age and union stability, none was included in this analysis. This exclusion was decided upon because there were only 520 values for the father's age at pregnancy in the entire dataset.

Age endogamy. For the reason given in the preceding paragraph, no variables concerning age endogamy were used in this analysis.

Type of job. In keeping with the logic previously set forth, a dummy variable was created to ascertain the possible relationship between having a managerial/specialty occupation job as defined by 1990 Census Industry codes and relationship status. It was dropped from final analyses because including it with all the other variables included in the final model reduced the sample size to only 637 respondents

Wantedness of focal child. Again partly following the lead of Oropesa and Landale [29], a dummy variable regarding the wantedness of the focal child was created. If a respondent answered "wanted to become preg sooner or wanted to become preg then," said dummy variable was coded as 1 . This variable was dropped in final analyses, however, because bivariate regressions with an aforementioned dummy variable pertaining to living situation showed that a 1 value for the child wantedness dummy raised the probability of a 1 value for the living situation dummy by $26.4 \%$ for the entire dataset $(p<0.0001)$. Lastly, including it alongside all the other variables ultimately included reduced the sample size to only 960 respondents.

\section{Results}

\subsection{Descriptive Table ( $\mathrm{N}=1452)$}

\begin{tabular}{lr}
\hline Divorced or separated (\%) & $11.60 \%$ \\
Age first union - age first sexual experience (\%) & $36.00 \%$ \\
before 27 - before 17 & $56.20 \%$ \\
before 27 - 17 or after & $0.60 \%$ \\
27 or after - before 17 & $7.30 \%$ \\
27 or after - 17 or after & $7.00 \%$ \\
Education - combined household income at time of pregnancy $(\%)$ & \\
Bachelor's degree - at least $\$ 25,000$ & \\
\hline
\end{tabular}




\section{Continued}

no Bachelor's degree - at least $\$ 25,000$

Bachelor's degree - under $\$ 25,000$

no Bachelor's degree - under $\$ 25,000$

$69.90 \%$

Respondent completed less than 12 grades - father of focal child completed 16 or more (\%) $\quad 0.90 \%$

Respondent identified herself as Puerto Rican - father of focal child Puerto Rican (\%)

Living situation at time of conception - partner characteristics (\%)

lived with father of focal child - had been to jail or hit respondent

$4.90 \%$

did not live with father of focal child - had been to jail or hit respondent

lived with father of focal child - had neither been to jail nor hit respondent

did not live with father of focal child - had neither been to jail nor hit respondent

$15.40 \%$

No prior child (\%)

Focal child female (\%)

$49.00 \%$

Respondent's financial situation - health of loved ones (\%)

unable to pay bills - someone close was not well

able to pay bills - someone close was not well

unable to pay bills - noone close was not well

$10.90 \%$

able to pay bills - noone close was not well

$58.70 \%$

Religious denomination - attended services at least once weekly (\%)

Protestant - at least once weekly

Protestant - less than once weekly

Catholic - at least once weekly

Catholic - less than once weekly

not Protestant or Catholic - at least once weekly

$3.00 \%$

not Protestant or Catholic - less than once weekly

$11.30 \%$

Number of births prior to focal child (M)

\subsection{Bivariate Results}

\begin{tabular}{cc}
\hline Independent Variables & $\begin{array}{c}\text { Coef. with } \\
\text { dependent variable }\end{array}$ \\
\hline Age first union - age first sexual experience & \\
before 27 - before 17 & $-0.313^{\star * * *}$ \\
before 27 - 17 or after & 0.142 \\
27 or after - before 17 & 043 \\
27 or after - 17 or after & \\
Education - combined household income at time of pregnancy & $-0.487^{* *}$ \\
Bachelor's degree - at least $\$ 25,000$ & $-0.422^{* * * *}$ \\
no Bachelor's degree - at least $\$ 25,000$ & $-0.725^{\star * *}$ \\
Bachelor's degree - under $\$ 25,000$ & \\
\hline
\end{tabular}




\section{Continued}

no Bachelor's degree - under $\$ 25,000$

Respondent completed less than 12 grades - father of focal child completed 16 or more

Respondent identified herself as Puerto Rican - father of focal child Puerto

lived with father of focal child - had been to jail or hit respondent

did not live with father of focal child - had been to jail or hit respondent

lived with father of focal child - had neither been to jail nor hit respondent

did not live with father of focal child - had neither been to jail nor hit respondent

0.696

No prior child

Focal child female

0.058

Respondent's financial situation - health of loved ones

unable to pay bills - someone close was not well

$0.588^{\star * * *}$

able to pay bills - someone close was not well

$-0.407^{* * * *}$

unable to pay bills - noone close was not well

able to pay bills - noone close was not well

Religious denomination - attended services at least once weekly

Protestant - at least once weekly

Protestant - less than once weekly

Catholic - at least once weekly

Catholic - less than once weekly

not Protestant or Catholic - at least once weekly

not Protestant or Catholic - less than once weekly

Number of births prior to focal child

0.018

Note: ${ }^{*}$ indicates significance at the 0.1 level, ${ }^{* *}$ indicates significance at the 0.05 level, ${ }^{* * *}$ indicates at the 0.01 level, and ${ }^{* * *}$ indicates significance at the 0.001 level.

\subsection{Multivariate Results}

\section{Independent variables}

Age first union - age first sexual experience

before 27 - before 17

before $27-17$ or after

27 or after - before 17

27 or after - 17 or after

Education - combined household income at time of pregnancy 


\section{Continued}

$$
\begin{gathered}
\text { Bachelor's degree - at least } \$ 25,000 \\
\text { no Bachelor's degree - at least } \$ 25,000 \\
\text { Bachelor's degree - under } \$ 25,000 \\
\text { no Bachelor's degree - under } \$ 25,000
\end{gathered}
$$$$
-0.343
$$$$
-0.473^{* * * *}
$$$$
-0.672^{*}
$$

Respondent completed less than 12 grades - father of focal child completed 16 or more

Living situation at time of conception - partner characteristics

lived with father of focal child - had been to jail or hit respondent

$0.611^{* * * *}$

did not live with father of focal child - had been to jail or hit respondent

lived with father of focal child - had neither been to jail nor hit respondent

did not live with father of focal child - had neither been to jail nor hit respondent

Respondent's financial situation - health of loved ones

unable to pay bills - someone close was not well

able to pay bills - noone close was not well

Religious denomination - attended services at least once weekly

$$
\begin{array}{cc}
\text { Protestant - at least once weekly } & -0.309 \\
\text { Protestant - less than once weekly } & \\
\text { Catholic - at least once weekly } & -0.048 \\
\text { Catholic - less than once weekly } & -0.301^{\star *} \\
\text { not Protestant or Catholic - at least once weekly } & -0.353 \\
\text { not Protestant or Catholic - less than once weekly } & -0.434^{\star *} \\
\text { Number of births prior to focal child } & -0.086^{\star}
\end{array}
$$

Note: ${ }^{*}$ indicates significance at the 0.1 level, ${ }^{* *}$ indicates significance at the 0.05 level, ${ }^{* *}$ indicates at the 0.01 level, and ${ }^{* * *}$ indicates significance at the 0.001 level.

In the bivariate regressions, 11 out of the 22 variables were significant at the 0.05 level, with 12 being significant at the less restrictive 0.1 level, 7 being significant at the more restrictive 0.01 level, and 6 being significant at the very restrictive 0.001 level. In regards to strength of relationship with the dependent variable, the dummy pertaining to cases where the respondent had completed less than 12 years of education while her partner had completed at least 16 clearly had the strongest relationship. The dummy variable for when the respondent had at least finished college and the combined household income was less than 25 thousand dollars and the dummy for couples who did not live together at time of conception and in which the respondent's partner had not been to jail or hit her, meanwhile, had the second and third strongest relationships with union 
stability with nearly equal coefficients of -0.725 and 0.696 , respectively. When analyses became multivariate rather than bivariate, many noteworthy changes occurred. Starting with the age first union-age first sexual experience interactions, the dummy for cases where the respondent entered into the union in question before age 27 and had not experienced sexual intercourse until after her $17^{\text {th }}$ birthday became significant at the. 05 level, whereas it had not been significant previously at even the 0.1 level. At the same time, the coefficients for each of the union-age at first time interaction variables became much larger (i.e. coefficients went from $0.313,-0.142$, and 0.043 to $1.156,0.995$, and 0.925 for the dummies pertaining to entering a union before 27 and having sex before 17, entering a union before 27 and delaying sex until at least the age of 17, and for delaying entering a union until after 27 and having sex before reaching the age of 17 , respectively).

In regards to the other variables in the model, the variable for instances where the respondent had completed at least college and the combined household income at time of pregnancy was over $\$ 25,000$ became insignificant at the 0.1 level. Meanwhile, the dummy for cases where the respondent had attained at least a Bachelor's degree and her combined household income during pregnancy was less than $\$ 25,000$ remained significant only at the 0.1 level. As for the dummy pertaining to cases where the couple did not live together at time of conception and the father of the focal child had hit the respondent or been to jail, it became significant at only the 0.1 level. The effect of the focal child being the couple's first child, meanwhile, became significant at the 0.1 level and its effect on the dependent variable nearly doubled (i.e. a 1 value for it lowered the chances for the dependent variable equaling 1 by nearly $10.3 \%$ in multivariate calculations instead of by $5.2 \%$ as in a bivariate calculation). The other fertility-related variable, meanwhile, became significant at the 0.1 level and had its coefficient rise from 0.018 to 0.086 , which represents a meaningful difference for larger values of it. As for the effect of the respondent being unable to pay her bills and having someone close to her be not well, its positive effect on union dissolution was reduced from $22.2 \%$ to $14.4 \%$.

Turning to cases where the respondent attended religious services less than once a week and identified herself as Catholic, this interaction became significant at the 0.05 level and its coefficient rose to -0.301 from -0.143 , thereby increasing its effect on the dependent variable by $2.3 \%$. The effect of attending religious services infrequently and of not being Catholic or Protestant, meanwhile, went from being insignificant at even the 0.1 level to being significant at the 0.05 level and it went from having virtually a nil effect on union dissolution to affecting it by $16.3 \%$. Lastly, the effect of the respondent having completed less than 12 years of schooling while her partner had completed 16 or more went from being the largest to being the $4^{\text {th }}$ largest behind each of the three age first union age first time interactions (although it should be pointed that the interaction regarding respondents who entered into a union before 27 and had first sexual intercourse after 17 was not significant at even the 0.1 level). 
There were other changes in results when going from bivariate to multivariate analyses, but they were of much less substantive importance. They were as follows: 1) the dummy for respondents who entered a union before the age of 27 and who engaged in sexual intercourse before the age of 17 became insignificant at the 0.001 level; 2) the dummy for respondents who had not attained at least a Bachelor's degree and whose combined household income during pregnancy was at least $\$ 25,000$ had its p-level rise to 0.001 .

\section{Discussion}

The people who did not delay both their entry into their first union and into sexual intercourse were the ones most likely to be divorced or separated. Interestingly, the group second most likely to be divorced or separated was the one whose members delayed sexual intercourse but did not delay their first union until later on in their 20s, thus repeating the implication from prior research that age at first union is the most substantial predictor of relationship status.

As for the variables regarding living arrangement and partner quality, it must be pointed out that each of the three variables in the final multivariate regression had substantial effects on the dependent variable and were all significant at the 0.1 level. The interaction representing cases where the couple lived together at time of conception and where the male had hit the respondent or been to jail and the interaction representing cases where the couple did not live together at time of conception and the male had not hit the respondent or been to jail being significant at the 0.05 level. Perhaps the most interesting fact about these variables is that it was the interaction representing cases where the couple did not live together and the father had not been to jail or hit his partner which had the largest coefficient, not the interaction for cases where the couple did live together and the father had been to jail or hit his partner. While their coefficients were roughly equal, it is interesting that in regards to this dataset, not living with the father was slightly more deleterious to the chances of a union proving stable than living with someone who hit his partner or had been to jail.

Moving to other multivariate results, it is very interesting that the interaction representing respondents who had a partner with 16 or more years of schooling but less than 12 themselves had such a substantial impact on the dependent variable. With its positive coefficient of 0.844 , it implies that, at least in the context of the PRMIHS dataset, there was a much greater chance for a union to end when the man had attained a substantially higher level of education than the female (i.e. all else held equal, this condition raised the chances for a 1 value for the dependent variable by nearly $30 \%$ ). This finding must be treated cautiously, however, for the dummy in question had a positive value only 13 times in the final sample. Nevertheless, it is a finding worth taking note of, especially considering that it is consistent with prior relationships found between union status and educational endogamy. The exact reason for this finding, however, cannot be ascertained from the examined survey. It is possible that the male after a cer- 
tain point attempts to "trade up" by attaining a more educated wife. At the same time, however, it could be the case that education level/BA attainment is a proxy for communication as previous authors have argued [9] [22] [23]. This finding implies that the woman's communication skills are more important for union survival than the man, a proposition supported by the finding that a positive value for an interaction representing cases where the respondent had at least a Bachelor's degree and her partner had completed less than 12 years of schooling predicts a negative value for the dependent variable perfectly. Similar to the interaction for cases where the respondent had not finished at least 12 years of schooling and the father had completed 16 or more, however, this result must be viewed cautiously because there are only 15 instances of this situation.

There is yet another interesting finding in regards to coefficient size when one examines the education-income interaction variables. While it did not reach significance at the.05 level, the interaction for cases where the respondent had at least a Bachelor degree and her combined household income during pregnancy was under $\$ 25,000$ had the largest coefficient for these three variables and it will not be discarded here considering that its $\mathrm{p}$-value was barely above.05 ( $\mathrm{p}=$ 0.052). This finding indicates that education is slightly more important for union stability than income. Nevertheless, the interaction for cases where the mother had not attained at least a Bachelor's degree and her combined household income during pregnancy was at least $\$ 25,000$ was statistically significant at the.05 level and it did not have an effect to scoff at on the dependent variable (i.e. a 1 value for this independent variable reduced the chances of a 1 value for the dependent variable by nearly $18.1 \%$ ). This fact implies that it is sufficient that a couple have either money or at least one educated partner (in this case, the woman) to lower its likelihood of ending in divorce or separation. In one final point on these variables, it is surprising that the interaction representing cases where the respondent had attained at least a Bachelor's degree and whose combined household income during pregnancy was at least $\$ 25,000$ had the smallest coefficient and would only be considered significant at a rather relaxed alpha level of 0.15 . One would have expected this variable to have the largest coefficient for this group of variables; this expectation was clearly not met, however.

For the stressful event interaction variables, there are two things worth discussing. One, the signs for the two significant interactions were in opposite directions (i.e. the coefficient for the dummy pertaining to respondents who could not pay their bills and did not have a loved one be not well was positive, whereas the dummy representing respondents who could pay their bills and had someone close to them be not well was negative), thus calling into doubt the wisdom of putting these two variables into the same index variable as had been done in prior research [29]. Two, the coefficient for the interaction representing respondents who could pay their bills and who had a loved one be not well was slightly larger than its inverse (i.e. the interaction representing respondents who could pay their bills and did not have someone close to them be not well ( 0.465 and 0.37 , respectively)), thereby implying that having a loved one be ill has a some- 
what stronger "pulling together" effect on couples than any "pulling apart" effect of not being able to pay bills (i.e. a 1 value for the former interaction affects the dependent variable by $18.1 \%$, instead of by $14.4 \%$ as a 1 value for the latter one does).

Moving on to the variables dealing with religion, only two attained significance at even the relaxed 0.1 level (i.e. the interaction for Catholics who attended services less than once a week and the interaction for respondents who were neither Catholic nor Protestant and who attended services less than once a week). The latter dummy also had the largest coefficient of the group $(-0.434)$, meaning that a 1 value for this interaction reduced the chance of the dependent variable equaling one by nearly $16.6 \%$. The coefficient for the dummy representing Catholics who attended services less than once a week, meanwhile, lowered said chances by $11.8 \%$. It is very interesting that nonfrequently church attending Catholics are less likely in this dataset to be divorced or separated than frequent church attending Roman Catholics and frequent church attending Protestants. Lastly, it should be noted that although only two of these five variables were statistically significant, all were in the expected direction (i.e. negative).

As for the variables regarding the actual child and fertility history, the dummy for cases where there was no prior child and the continuous variable for the number of births prior to the focal child both had negative coefficients and were significant at the 0.1 level. The effect of the child at the focus of the PRMIHS being the first child was to reduce the chances of the dependent variable equaling 1 by approximately $10.3 \%$, whereas each child had prior to the focal child reduced said chances by nearly 3.6\%. This effect may not seem like much at first glance, but it is noteworthy considering that 193 respondents in the final sample had 3 or more children prior to the focal child.

\section{Parting Thoughts}

This analysis of the Puerto Rican Maternal and Infant Health Study dataset provides support for the assertion that relationships fail primarily because of the people in them. The relationships which turned out to be the least stable, regardless of which dummy variables were used, were the ones where the respondent had not delayed entering into their first union until later in life, particularly into their late 20s, and the ones in which the male exhibited undesirable qualities by hitting his partner or going to jail. While it of course could be argued that it is the stress of having one's partner going to jail or the possible negative employment consequences in the future for said partner that is truly affecting unions, such an argument in this author's opinion mistakes an effect for a true cause.

Moving on to another point, perhaps the most interesting finding in this analysis was that the best predictors of union stability were the interaction representing cases where the respondent entered the union before 27 and engaged in sexual intercourse before 17 and the interaction representing cases 
where the respondent entered the union before 27 and engaged in sexual intercourse after 17. While it is possible that later age at first sexual intercourse and at first union could be driven by things such as low attractiveness and being socially hermetic; a 2012 study found that adolescents who reported first sexual intercourse at a later date than other adolescents actually were not less attractive physically [57]. Moving on, it should be noted that these two variables, age at first union and age at first sexual intercourse, quite possibly pertain to the aspects of life most under the control of the actual respondent compared to the other aspects of life examined in this study. Income can be affected by things such as a weak economy or being friends with someone who has hiring power, educational attainment can be affected by something such as family finances dictating that schooling must be foregone for an additional regular paycheck, etc. At what age one first enters into a union or engages in first sexual intercourse, however, are intimate decisions presumably not heavily or as heavily affected by such externalities. Perhaps divorce falls into this category of being an intimate decision, not an economic or rational one as it has primarily been thought of in recent decades.

If the final sentence of the preceding paragraph is correct, it would dovetail with studies showing that the reasons given most frequently by divorcees for their divorces oftentimes include things such as extramarital sex and abuse [13] [58] [59] [60] [61] [62]. South and Lloyd, it should be added, pointed out in their 1995 study that even with conservative estimates, a substantial number of divorces in their work were presaged by extramarital sex [13]. The usefulness of examining sexual behavior to understand marital stability has been documented in other studies examining sex as well, particularly premarital sex [63] [64]. Notably, a 2012 study on young adults found that later age at first sexual intercourse was associated with reduced odds of marriage or nonmarital cohabitation, with fewer romantic partners in adulthood, and with greater relationship satisfaction [57]. Furthermore, although not examining unions, some recent studies show that an economic, rational choice viewpoint is sometimes limited or not the most explanatory viewpoint [65] [66] [67]. Given this fact, along with the others presented in this paper, it may well be the case that the primary focus on union status should return to where it had been before: on people and emotions.

\section{References}

[1] Becker, G.S. (1973) A Theory on Marriage. The Journal of Political Economy, 81, 813-846. https://doi.org/10.1086/260084

[2] Becker, G.S. (1991) A Treatise on Family. Harvard University Press, Cambridge.

[3] Cooke, L.P. (2004) The Gendered Division of Labor and Family Outcomes in Germany. Journal of Marriage and the Family, 66, 1246-1259. https://doi.org/10.1111/j.0022-2445.2004.00090.x

[4] Dechter, A.R. (1992) The Effect of Women's Economic Independence on Union Dissolution. Working Paper 92-28. Center for Demography and Ecology, University of Wisconsin, Madison, WI. 
https://www.popline.org/node/339983

[5] Bernard, J. (1981) The Good Provider Role: Its Rise and Fall. American Psychologist, 36, 1-12. https://doi.org/10.1037/0003-066X.36.1.1

[6] Cherlin, A. (1979) Work Life in Marital Dissolution. In: Levinger, G. and Moles, O.C., Eds., Divorce and Separation, Basic Books. New York, 151-166.

[7] D’Amico, R. (1983) Status Maintenance or Status Competition? Wife's Relative Wages as a Determinant of Labour Supply and Marital Instability. Social Forces, 61, 1886-1205. https://doi.org/10.2307/2578286

[8] Davis, K. (1984) Wives and Work: The Sex Role Revolution and Its Consequences. Population and Development Review, 10, 397-417. https://doi.org/10.2307/1973512

[9] Ono, H. (1998) Husbands and Wives Resources and Marital Dissolution. Journal of Marriage and the Family, 60, 674-689. https://doi.org/10.2307/353537

[10] Ressler, R.W. and Waters, M.S. (2000) Female Earnings and the Divorce Rate: A Simultaneous Equations Model. Applied Economics, 32, 1889-1898. https://doi.org/10.1080/000368400425107

[11] Spitze, G. and South, S.J. (1985) Women's Employment, Time Expenditure, and Divorce. Journal of Family Issues, 6, 307-329. https://doi.org/10.1177/019251385006003004

[12] Becker, E., Landes, E. and Michaels, R. (1977) An Economic Analysis of Marital Instability. Journal of Political Economy, 85, 1141-1187. https://doi.org/10.1086/260631

[13] South, S.J. and Lloyd, K.M. (1995) Spousal Alternatives and Marital Dissolution. American Sociological Review, 60, 21-35. https://doi.org/10.2307/2096343

[14] Green, W.H. and Quester, A.O. (1982) Divorce Risk and Wives Labor Supply Behavior. Social Science Quarterly, 63, 16-27. https://www.popline.org/node/394527

[15] Sayer, L.C. and Bianchi, S.M. (2000) Women's Economic Independence and the Probability of Divorce. Journal of Family Issues, 21, 906-943. https://doi.org/10.1177/019251300021007005

[16] South, S.J. and Spitze, G. (1986) Determinants of Divorce over the Marital Life Course. American Sociological Review, 51, 583-590. https://doi.org/10.2307/2095590

[17] South, S.J. (2001) Time Dependent Effects of Wives' Employment on Marital Dissolution. American Sociological Review, 66, 226-245. https://doi.org/10.2307/2657416

[18] Bose, S. and South, S.J. (2003) Sex Composition of Children and Marital Disruption in India. Journal of Marriage and the Family, 65, 996-1006. https://doi.org/10.1111/j.1741-3737.2003.00996.x

[19] Diekman, A. and Schmidheiny, K. (2004) Do Parents of Girls Have a Higher Risk of Divorce? An Eighteen-Country Study. Journal of Marriage and the Family, 66, 651-660. https://doi.org/10.1111/j.0022-2445.2004.00044.x

[20] Morgan, S.P., Lye, D.N. and Condran, G.A. (1988) Sons, Daughters, and the Risk of Marital Disruption. American Journal of Sociology, 94, 110-129. https://doi.org/10.1086/228953

[21] Hannan, M., Tuma, N. and Groeneveld, L.P. (1977) Income and Independence Effects on Marital Dissolution: Results from the Seattle and Denver Income-Maintenance Experiments. American Journal of Sociology, 84, 611-633. https://doi.org/10.1086/226829

[22] Martin, T.C. and Bumpass, L.L. (1989) Recent Trends in Marital Disruption. De- 
mography, 26, 37-51. https://doi.org/10.2307/2061492

[23] Waite, L.J. and Lillard, L.A. (1991) Children and Marital Disruption. The American Journal of Sociology, 96, 930-953. https://doi.org/10.1086/229613

[24] Hadaway, C.K., Marler, P.L. and Chaves, M. (1993) What the Polls Don't Show: A Closer Look at Church Attendance. American Sociological Review, 58, 741-752. https://doi.org/10.2307/2095948

[25] Karp, J.A. and Brockington, D. (2005) Social Desirability and Responsive Validity: A Comparative Analysis of Overreporting Voter Turnout in Five Countries. The Journal of Politics, 67, 825-840. https://doi.org/10.1111/j.1468-2508.2005.00341.x

[26] Hoffman, S.D. and Duncan, G.J. (1995) The Effect of Incomes, Wages, and AFDC benefits on Marital Disruption. The Journal of Human Resources, 30, 19-41. https://doi.org/10.2307/146189

[27] DeMaris, A. (2000) Till Discord Do Us Part: The Role of Physical and Verbal Conflict in Union Disruption. Journal of Marriage and the Family, 62, 683-692. https://doi.org/10.1111/j.1741-3737.2000.00683.x

[28] DeMaris, A. (2001) The Influence of Intimate Violence on Transitions out of Cohabitation. Journal of Marriage and the Family, 63, 235-246. https://doi.org/10.1111/j.1741-3737.2001.00235.x

[29] Oropesa, R.S. and Landale, N.S. (2005) Equal Access to Income and Union Dissolution among Puerto Ricans. Journal of Marriage and the Family, 67, 173-190. https://doi.org/10.1111/j.0022-2445.2005.00013.x

[30] Balakrishnan, T.R., Rao, K.V., Lapierre-Adamcyk, E. and Krotki, K.J. (1987) A Hazard Model Analysis of the Covariates of Marriage Dissolution in Canada. Demography, 24, 395-406. https://doi.org/10.2307/2061305

[31] Weiss, Y. and Willis, R.J. (1997) Match Quality, New Information, and Marital Dissolution. Journal of Labor Economics, 15, S293-S329. https://doi.org/10.1086/209864

[32] Bramlett, M.D. and Mosher, W.D. (2001) First Marriage Dissolution, Divorce, and Remarriage: United States. Advance Data, Number 323, May 31, Department of Health and Human Services, Washington DC. https://www.cdc.gov/nchs/data/ad/ad323.pdf

[33] Whittington, L.A. and Alm, J. (1997) Till Death or Taxes Do Us Part. The Journal of Human Resources, 32, 388-412. https://doi.org/10.2307/146220

[34] Bennett, N.G., Blanc, A.K. and Bloom, D.E. (1988) Commitment and the Modern Union: Assessing the Link between Premarital Cohabitation and Subsequent Marital Stability. American Sociological Review, 53, 127-138. https://doi.org/10.2307/2095738

[35] Brines, J. and Joyner, K. (1999) The Ties That Bind: Principles of Cohesion in Cohabitation and Marriage. American Sociological Review, 64, 333-355. https://doi.org/10.2307/2657490

[36] Dush, C.M., Cohan, C.L. and Amato, P.R. (2003) The Relationship Between Cohabitation and Marital Quality and Stability: Change across Cohorts? Journal of Marriage and the Family, 65, 539-549. https://doi.org/10.1111/j.1741-3737.2003.00539.x

[37] Smock, P.J. and Mannning, W.D. (1997) Cohabitating Partners Economic Circumstances and Marriage. Demography, 34, 331-341. https://doi.org/10.2307/3038287

[38] Teachman, J.D., Thomas, J. and Paasch, K. (1991) Legal Status and the Stability of Coresidential Unions. Demography, 28, 571-586. https://doi.org/10.2307/2061423 
[39] Bitler, M.P., Gelbach, J.B., Hoynes, H.W. and Zavodny, M. (2004) The Impact of Welfare Reform on Marriage and Divorce. Demography, 41, 213-236. https://doi.org/10.1353/dem.2004.0011

[40] Gennetian, L.A. and Knox, V. (2004) The Effect of a Minnesota Welfare Reform Program on Marriage Stability Six Years Later. Population Research and Policy Review, 23, 567-593. https://doi.org/10.1007/s11113-004-2708-7

[41] White, L.K. (1990) Determinants of Divorce: A Review of Research in the Eighties. Journal of Marriage and the Family, 52, 904-912. https://doi.org/10.2307/353309

[42] Kitson, G.C, Babri, K.B. and Roach, M.J. (1985) Who Divorces and Why: A Review. Journal of Family Issues, 6, 255-293. https://doi.org/10.1177/019251385006003002

[43] Morgan, S.P. and Rindfuss, R.R. (1985) Marital Disruption: Structural and Temporal Dimensions. American Journal of Sociology, 90, 1055-1077. https://doi.org/10.1086/228176

[44] Jockin, V., McGue, M. and Lykken, D. (1996) Personality and Divorce: A Genetic Analysis. Journal of Personality and Social Psychology, 71, 288-299. https://doi.org/10.1037/0022-3514.71.2.288

[45] Johnson, W., McGue, M., Krueger, R.F. and Bouchard Jr., T.J. (2004) Marriage and Personality: A Genetic Analysis. Journal of Personality and Social Psychology, 86, 285-294. https://doi.org/10.1037/0022-3514.86.2.285

[46] McGue, M. and Lykken, D.T. (1992) Genetic Influence on Risk of Divorce. Psychological Science, 3, 368-373. https://doi.org/10.1111/j.1467-9280.1992.tb00049.x

[47] Booth, A. and Dabbs Jr., J.M. (1993) Testosterone and Men's Marriages. Social Forces, 72, 463-477. https://doi.org/10.2307/2579857

[48] Dabbs, Jr., J.M. (1992) Testosterone and Occupational Achievement. Social Forces, 70, 813-824. https://doi.org/10.2307/2579755

[49] Dabbs, Jr., J.M. and Morris, R. (1990) Testosterone, Social Class, and Antisocial Behavior in a Sample of 4,462 Men. Psychological Science, 1, 209-211. https://doi.org/10.1111/j.1467-9280.1990.tb00200.x

[50] Bouchard, Jr., T.J. and Loehlin, J.C. (2001) Genes, Evolution, and Personality. Behavior Genetics, 31, 243-273. https://doi.org/10.1023/A:1012294324713

[51] Teachman, J.D. (2002) Stability across Cohorts in Divorce Risk Factors. Demography, 39, 331-351. https://doi.org/10.1353/dem.2002.0019

[52] Eysenck, H.J. (1980) Personality, Marital Satisfaction, and Divorce. Psychological Reports, 47, 1235-1238. https://doi.org/10.2466/pr0.1980.47.3f.1235

[53] Johnson, J. and Harris, W. (1980) Personality and Behavioral Characteristics Related to Divorce in a Population of Male Applicants for Psychiatric Evaluation. Journal of Abnormal Psychology, 89, 510-513. https://doi.org/10.1037/0021-843X.89.3.510

[54] Kiernan, K.E. (1986) Teenage Marriage and Marital Breakdown: A Longitudinal Study. Population Studies, 40, 35-54. https://doi.org/10.1080/0032472031000141826

[55] Rockwell, H.C., Elder, Jr., H.C. and Ross, D.J. (1979) Psychological Patterns in Marital Timing and Divorce. Social Psychology Quarterly, 42, 399-404. https://doi.org/10.2307/3033810

[56] Niebuhr, R. (1952) The Irony of American History. Charles Schreibner's Sons, New York.

[57] Harden, K.P. (2012) True Love Waits? A Sibling-Comparison Study of Age at First Sexual Intercourse and Romantic Relationships in Young Adulthood. Psychological 
Science, 23, 1324-1336. https://doi.org/10.1177/0956797612442550

[58] Albrecht, S.L., Bahr, M.H. and Goodman, K.L. (1983) Divorce and Remarriage: Problems, Adaptations, and Adjustments. Greenwood Press, Westport, CT.

[59] Burns, A. (1984) Perceived Causes of Marriage Breakdown and Conditions of Life. Journal of Marriage and the Family, 37, 551-562. https://doi.org/10.2307/352597

[60] Granvold, D.K., Pedler, L.M. and Schellie, S.G. (1979) A Study of Sex Role Expectations and Female Postdivorce Adjustment. Journal of Divorce, 2, 383-393. https://doi.org/10.1300/J279v02n04_05

[61] Kitson, G.C. and Sussman, M.B. (1982) Marital Complaints, Demographic Characteristics, and Symptoms of Mental Distress in Divorce. Journal of Marriage and the Family, 44, 87-101. https://doi.org/10.2307/351265

[62] Levinger, G. (1966) Sources of Marital Dissatisfaction among Applicants for Divorce. American Journal of Orthopsychiatry, 36, 803-807. https://doi.org/10.1111/j.1939-0025.1966.tb02407.x

[63] Kahn, J.R. and London, K.A. (1991) Premarital Sex and the Risk of Divorce. Journal of Marriage and the Family, 53, 845-855. https://doi.org/10.2307/352992

[64] Teachman, J.D. (2003) Premarital Sex, Premarital Cohabitation, and the Risk of Subsequent Marital Dissolution among Women. Journal of Marriage and the Family, 65, 444-455. https://doi.org/10.1111/j.1741-3737.2003.00444.x

[65] Grant, R.W. (2006) Ethics and Incentives: A Political Approach. American Political Science Review, 100, 29-39. https://doi.org/10.1017/S0003055406061983

[66] Kahneman, D. and Tversky, A. (1979) Prospect Theory: An Analysis of Decision under Risk. Econometrica, 47, 263-292. https://doi.org/10.2307/1914185

[67] Leach, W.D. and Sabatier, P.A. (2005) To Trust an Adversary: Integrating Rational and Psychological Models of Collaborative Policymaking. American Political Science Review, 99, 491-503. https://doi.org/10.1017/S000305540505183X

Submit or recommend next manuscript to SCIRP and we will provide best service for you:

Accepting pre-submission inquiries through Email, Facebook, LinkedIn, Twitter, etc. A wide selection of journals (inclusive of 9 subjects, more than 200 journals)

Providing 24-hour high-quality service

User-friendly online submission system

Fair and swift peer-review system

Efficient typesetting and proofreading procedure

Display of the result of downloads and visits, as well as the number of cited articles

Maximum dissemination of your research work

Submit your manuscript at: http://papersubmission.scirp.org/

Or contact ojapps@scirp.org 